Tourism Research Journal

E-ISSN: 2958-9839

2020, Vol. 4 No. 2

\title{
The Significance of Destination Image for Freediving as a Form of Alternative Tourism in Tulamben, Bali
}

\author{
Yulia Lintangkawuryan \\ Sekolah Tinggi Pariwisata Trisakti \\ yulialintang@stptrisakti.ac.id
}

\begin{abstract}
In the last few years, freediving has been growing rapidly as a form of alternative tourism. These activities aim at hunting view, spearfishing, taking photos, witnessing the beauties of the objects like the flora, fauna, and the archaeology of underwater. This research aims to give a descriptive potential to increase freediving awareness as an alternative activity to explore the underwater flora and fauna heritage of Tulamben and bring them into tourism. The history and development of Tulamben are intimately linked to the sea. Tulamben area possesses a rich underwater cultural and natural heritage, which reflects its identity and should be protected for future generations. This new interest is becoming more famous for its underwater richness. This move also guides some to form a new underwater sports center, especially for freediving enthusiasts, to contribute to the region's potential improvement. This project also aims to improve extreme underwater sports like freediving, which is now a hobby than a sport. The research method carried out in this study is a qualitative method with a descriptive approach because this study aims to obtain a complete picture of freediving as a form of alternative tourism in Tulamben, Bali. From the result, it can be concluded that freediving could be potential alternative tourism in Tulamben for its good destination image.
\end{abstract}

Keywords: Freediving, Alternative Tourism, Underwater Tourism, Tulamben

Tourism Research Journal, Volume 4 (2), 2020 
The Significance of Destination Image For Freediving as a Form of Alternative Tourism in Tulamben, Bali

\section{A. Introduction}

In some countries, many parts of the world, one of the largest and dynamic industries that support and even drive the country's economy, obviously is tourism no exception in Indonesia. Underwater tourism is amongst one of the most popular tourism activities in recent years. Indonesia benefits a lot from underwater tourism since it is applicable for all seasons, supportive natural circumstances, and presenting environmental protection (Junaedi, 2007). People spend their time in underwater tourism activities as their leisure time in some tropical countries such as Indonesia.

Freediving tourism has grown rapidly over the past years throughout the world due to the great popularity of the media's publication. Recreational freediving also becomes a sector that provides a high level of economic, cultural, social, ecological tourism and a high-performance field for professionals in the freediving sector. Of course these reasons have a beneficial impact on local and national economies, where it takes place. Several tourism centers in various countries began to conduct activities focused on freediving and tourism activities (courses, travel packages, adventure, exploration). They gained great economic values such as centers in the Maldives Islands, Philippines, Mediterranean, Caribbean, Florida, and Thailand. With some similarities, these countries with Indonesia such as climate, underwater flora, and fauna have made consistent investments in freediving tourism and made this activity a supporting machine for the sector of tourism in their important regions. The natural visual and parts of underwater life have been carefully protected in these areas. They are supported by a wide range of natural and artificial potentials such as man-made reefs and shipwrecks to prepare magnificent environments for underwater tourism and water sports such as freediving enthusiasts (Broadwater, 2001).

With its beautiful bays of various sizes and a wealth of nature, history, and culture, Indonesia is one of the most beautiful holiday destinations in Southeast Asia and the rest of the world (Cederlund, 2001). With clean and clear waters, climate conditions, endless bays of beauty, adequate tourism infrastructure, Indonesia is ideally located to establish an underwater tourism hub, especially freediving. North coastal area in Bali, including Tulamben is an ideal place to attract and develop diving tourism, potentially one of the most ideal diving destinations throughout Indonesia (Ghautama, 2011). As a land of immeasurable natural beauty, with by far the longest and most diverse coastline and the most islands of all the Indonesian countries, with an ideal geographical location, with a secure and civilized regime, with warm and clear waters that can be dived year-round, with spectacular sea beds without any dangerous sea life and extreme weather phenomena, with modern diving legislation and taking advantage of the favorable international conditions (lack of wars or terrorist attacks and extreme natural disasters that exist in competitor markets), Tulamben can and should expand into the freediving market.

Tourism Research Journal, Volume 4 (2), 2020 
The Significance of Destination Image For Freediving as a Form of Alternative Tourism in Tulamben, Bali

\section{B. Literature Review}

\section{Alternative Tourism}

Alternative tourism is a form of tourism activity that does not damage the environment, side with ecologists and avoids the negative impact of large-scale tourism development carried out on an area that is not very fast in development. Alternative tourism is tourism that appears to minimize the negative impact of mass tourism development that occurs to date. The negative impact of mass tourism or large-scale tourism is a threat to cultural sustainability, where culture is more commercialized than maintained authenticity and sustainability. Besides, the negative impact that can be dangerous is the destruction of natural resources where natural resources are massively exploited. In addition, alternative tourism is a tourism activity with the idea that means a small-scale development or a tourism activity presented to tourists, where all its activities also involve the community (Soeparno, 2010). So, it can be concluded that good tourism development and supporting which sustainability of resources both natural, cultural and human is an alternative tourism.

Owning to the adopted definition from the UN conference in Rome in 1963 which included alternative forms of tourism such as: business trips, congresses and conventions, visiting spa resorts, sporting events, visiting cultural and historical monuments, events, places of worship and pilgrimage departures and trips for picnics and walks. Of course this definition reinforces the major changes that occur in tourism, changes in income and demand, changes in travel motives, and tourist behavior. Approaches such as travel deals are prerequisites for meeting the wishes and preferences of visitors and prerequisites for competitiveness, quality and financial effects (profits). Simply adjusting the supply to tourism demand research involves the direction of flow in contemporary international tourism research and the characteristics of tourist clients namely their needs and interests. The needs of tourists find its expression in tourism demand and tourism supply. This in particular means that tourism as an important activity, should take into account the needs of visitors and tourists should be based on the study of these needs, namely on their motivational studies and factors that influence the choice of tourist destinations and types of tourist visits.

From the marketing aspect, a visitor needs now have more orientation on greater diversification with a wider range of potential services. Travelers are increasingly turning to destinations that offer new experiences, events, more value, and different activities. The challenge in the complex structure of tourism products is to adjust the weight of the various important elements that make up the product. In this context, you can see the level of education of the visitors who, in research motivational tours appear as an important factor of the tourist movement. With the increasing level of visitor education, tourist visits become more active, without focusing on what actions are implemented. This fact is very important to form tourism offerings, because research shows that tourism trends

Tourism Research Journal, Volume 4 (2), 2020 
The Significance of Destination Image For Freediving as a Form of Alternative Tourism in Tulamben, Bali

greatly take into account the increasing number of people with higher education. From the description, it can be concluded that there will be more people during the visit who will look for opportunities for different activities, such as recreation, culture, and entertainment as well as picnics and walks. Tourists will choose places that offer tourism with alternative activities.

Alternative tourism requires mutual understanding and equality between the guest and the host. It can be concluded that the idea of alternative tourism is very close to the idea of sustainable development. In general, we can mention the changes that occurred as a result of enormously rapid development and have a major impact on tourism. Tourism demand can no longer be considered a homogenized tourist market as new modern trends in tourism have contributed to the tourism market's segmentation and the new revolution in tourist movements. Thus create a tourism product optional purchase, and comes to the creation of modern methods in tourism operations. Tourists to meet their different travel needs are beginning to abandon the traditional mass tourism. All this is reflected in:

1. Customize existing to more suitable tourist destinations

2. Take a deeper look and try to find new, more innovative tourism products

3. Offer affordable prices to offer to tourists.

4. Create relationships through communication with potential users of the service directly.

The tourism component has evolved not only the sun and water. Nowadays, especially the younger generation, has an adventurous spirit and wants to explore. They are tired of the offers that have been given a lot and expect a new experience. Extreme sports are one of the things that many are looking for because in spending the holidays not only by lying on the beach, but these young tourists want challenging activities and need high adrenaline (Sopher, 1965). These include hiking, extreme cycling, snowboarding, fast water paddling, paragliding and others that have been very popular in the last ten years. Underscoring the situation here is an activity that does not take long to learn because extreme sports of untouched nature are adequate infrastructure.

Various tourism potentials are certainly affecting the establishment of specific destinations, which affects the ability of certain forms of tourism development in them. It will list some of the most mentioned special forms of tourism: religious tourism, sports tourism, rural tourism, culture, nautical tourism, holistic tourism, hunting tours, and more. Tourism, with its phenomenon and development, proves that it is an unlimited phenomenon. Natural spaces with their elements provide endless opportunities for tourism and tourism development representing the whole world. Tourist areas and destinations with various tourist attractions and attractions will invite visiting tourists (Nofiyanti et al., 2020). The development of tourism infrastructure that considers and the location will increase the accessibility of a tourist attraction which will increase the attractiveness of the tourist attraction itself. Apart from

Tourism Research Journal, Volume 4 (2), 2020 
The Significance of Destination Image For Freediving as a Form of Alternative Tourism in Tulamben, Bali

the various needs that come from above, other tourists' needs also need to be provided in tourist destination areas such as banks, pharmacies, hospitals, gas stations, shopping centers, and other (Fasandra et al., 2019).

\section{Freediving}

Freediving is a kind of underwater activities to dive into the water without involving the use of diving equipment or breathing apparatus. However, it relies on a diver's ability to hold his breath in the water until the diver returns to the surface. The term freediving arises from the word apnea (Greek: a-pnoia), which means without breathing. Literally, the word apnea is not related to these underwater activities. However, in current terminology, the word apnea is used to refer to freediving sports. Other uses in freediving activities are traditional fishing techniques, competitive and non-competitive freediving, competitive and non-competitive spearfishing and freediving photography, synchronized swimming, underwater football, underwater rugby, underwater hockey, underwater target shooting and snorkeling. Some range of "competitive apnea" disciplines in which competitors attempt to attain great depths, times, or distances on a single breath (Rebikoff, 1995).

Back in the previous times freediving was the only way, with the exception of the occasional use of reeds and leather breathing bladders. The divers faced the same problems as divers today, such as decompression sickness and blacking out during a breath hold. Freediving was practiced in ancient cultures to gather food, harvest resources such as sponge and pearl, reclaim sunken valuables, and help military aid campaigns (Ivanova et al., 1999).

Freediving is a way to enjoy the beauty of the sea without having to feel awkward and uncomfortable with scuba equipment. Freediving is also seen as an art form and is a form of expression of one's own and most others see freediving as a way to blend in with the oceans and the whole world. Ordinary people think more of freediving as an extreme sport because it requires calmness under tremendous pressure that differs from other extreme sports. Uniquely in Indonesia, for some traditional fishermen such as bajo tribe, freediving is a common daily thing to do to get fish.

Currently the activities that attract the most attention of the world community are extreme sports from apnea freediving competitions where athletes will compete in several disciplines. AIDA Federation Worldwide for breathlessness and diving. Established in 1992, AIDA manages and oversees record recognition, organizing competitions and setting standards for freediving education. Since 1993, AIDA International has inaugurated 230 world records.

Freediving as a recreational activity now is commonly practiced and takes some differences from scuba diving. Compared to scuba diving, freediving offers:

1. Freedom from cumbersome equipment and short preparation times.

2. Low cost.

Tourism Research Journal, Volume 4 (2), 2020 
The Significance of Destination Image For Freediving as a Form of Alternative Tourism in Tulamben, Bali

3. It is quiet and does not disturb fish, the noise of breathing and bubbles can be quite loud on open circuit scuba though rebreathers are much quieter.

4. Mobility and speed, but for a much more limited period.

5. No decompression time for deep dives, although it is possible to get decompression sickness, or taravana, from repetitive deep freediving with short surface intervals.

6. The lack of exhaled air bubbles on ascent gives greater visibility on ascent.

7. Accessibility, if the site can be walked to it can, potentially, be dived.

8. Appropriately skilled and fit freedivers can go as deep, or deeper than recreational scuba divers. The depth is limited only by the willingness to accept the risks; scuba diving is restricted by certification level.

Some potential risk could be found in freediving but could be safely executed with good safety and well tagged wide range of skills.

\section{Tulamben Diving Sites}

Development of the Tulamben diving site started with the ship site U.S.A.T. Liberty from the beginning until the current situation can be divided into three phases. The first phase was the beginning (1942-1979), the second phase was the pioneering (1980-2005), and the third phase is the development (2006-present).

The first phase lasted around 1942-1979. In this phase of the community's socio-economic condition in Tulamben has a very low income and is classified as one of the poor villages in Bali. In this phase, most of the population most occupation consist of fishermen, farmers, limestone miners in the sea, and gardening on dry and barren land. It has worsened and added more consequences of the eruption of Mount Agung. The next period was World War II which took place in 1942-1945. For the people of Tulamben village, this event is a very important historical momentum for them. The peak of momentum occurred on January 11, 1942. That's when the ship USAT. Liberty is torpedoed by Allied soldiers in the Lombok Strait. The rescue effort was assisted by Dutch ship Van Gent with the main purpose of sea port in Singaraja. Because of its heavy damaged condition they can not continue the travel and finally stranded in the coastal waters of Tulamben village. In the beginning, the U.S.A.T. Liberty ship was originally sunk on the coastline of Tulamben village. The entire vessel body can be seen clearly (Delfs, 2003).

On the other hand, the local community has never imagined that the wreck will give a tremendous blessing to the local community's economy as it is today. However, the routine activity as a fisherman, a limestone miner, and a farmer is still being lived as usual. The beginning of tourist visit in Tulamben Village area occurred in 1987 pioneered by a diving travel agent named Mister Hien from Denpasar. In that year, Mister Hien took several tourists to dive in the beach of Tulamben village with the cost of transporting diving equipment for one thousand rupiahs ( $\mathrm{Rp} 1.000,00)$ per set. At that time, tourists who come

Tourism Research Journal, Volume 4 (2), 2020 
The Significance of Destination Image For Freediving as a Form of Alternative Tourism in Tulamben, Bali

to the area is about $20-30$ people. As time goes by, the impact is so great with the visitors visit in the village area that local people appear to desire to compete to get sustenance from work serving tourists. While the number of tourists keep increasing, the service given by local people become less orderly. It is caused by unhealthy service practices among fellow local residents. To mediate the issue, the problem can be solved wisely through the customary device of local traditional Bendesa (I Nyoman Kariasa), problems can be solved wisely. It has since been established for the first time a guest servant organization (Porter/Helper). The customary village governs the management with the provisions and system agreement for the outcome. Income earned daily is deducted $20 \%$ for the indigenous village, the remaining $80 \%$ becomes their part. The following time, the area around U.S.A.T Liberty Shpwreck became more crowded with the number of tourist visits (Wells, 1995). To solve this problem a parking area was made on 5 May 2004, to facilitate the tourists in the loading and unloading goods so that tourists will feel more comfortable.

The increasing number of tourists coming to Tulamben, invite the involvement from the local government of Karangasem regency with the reason to preserve the environment and the existence of ship people. The local government intervened instead of making the citizens feel calm but rather, the public became restless. The community felt anxious because the government issued a rule against the public in the form of prohibition on finding/catching fish with a radius of 100 meters around the shipwreck. The unrest lasted for three years, but after being straightened by the traditional Bendesa of Tulamben, they grew in consciousness. The pioneering phase lasted around 1980-1997. In this phase, tourists visit both foreign and domestic every day with a rapid growth number. For the security and the comfortable reason of tourists, two additional parking lots were added, in the west in front of the boat (behind Hotel Puri Madha) and near the dive drop off spot. First-time hotel/restaurant facilities are Hotel Paradise and Hotel Mimpi. The dream Hotel was pioneered by Patrick Schwarz an entrepreneur originating in the country of Switzerland. This entrepreneur is very interested in the potential owned by Tulamben Beach. Both hotels began to be built in 1984 and started operating in 1986.

The development phase as a tourist destination took place from around 1997-present. In this phase, foreign, national, and local entrepreneurs flock to invest their investments in the area of Tulamben. The land that is considered strategic is constructed by investors to be hotels/family-villas, restaurant, dive operator, and other facilities related to diving tourism. The facility's building is almost entirely concentrated along the coastline and throughout the village, while the lands located at the back of the village and a bit far from the coastline utilized as plantation land. The rest is less productive land for farmland. The growing tourism in this village, make the local people who do not want to miss taking advantage of opportunities available gradually start to plunge and dissolve into the world of tourism and hospitality.

Tourism Research Journal, Volume 4 (2), 2020 
The Significance of Destination Image For Freediving as a Form of Alternative Tourism in Tulamben, Bali

Tulamben Village as a thriving tourist destination has fulfilled the requirements as the criteria for tourist destinations as stated by Cooper, et al (1995) which suggests that there are 4 (four) components that must be owned as a tourist attraction, namely:

1. attractions, such as interesting nature, charming regional cultures and performing arts.

2. Accessibility such as local transportation and transportation terminal presence.

3. Amenities such as accommodation, restaurant, and travel agency availability.

4. Ancillary Services is a tourism organization that is needed for tourist services such as destination marketing management organization, conventional and visitor Bureau.

The attractive component is the U.S.A.T. Liberty shipwreck, supported by six spot dive points, the natural beauty of the underwater and the natural panorama in the mainland. Components of accessibility, supported by smooth transportation, are on the main traffic route that connects Karangasem Regency with Buleleng. So this location with easy access, both from the provincial capital and from the district capital. Facilities in Tulamben's village are supported by 17 stalls, 3 mini markets, and 33 hotels/restaurant/villa. The last constructed tourist facility is the Bali Dive Resort, built in 2014, and has been operating since 2015. The Tourism Organization component that is needed for tourist services (ancillary services), which has existed in the village of Tulamben, among others, Diving tour guide, Porter/Helper, Jukung, management of Retribution, Massage, and security service (Edney, 2006).

\section{Research Methodology}

This study aims to find and measure freediving activities as a new niche market in underwater tourism activities of Tulamben, which is slowly evolving into a common pastime rather than a sport, and increasing diversification in tourism. In the study of freediving in Tulamben, a significant sample will be worked out academically.

This study uses Primary data and Secondary data. Primary data is data obtained by making observations directly to the location of the study and distributing questionnaires. Secondary data is obtained from outside the respondent but is related to the object under study and supports the theory. The data is obtained from literature and books as supporting primary data.

The research method carried out in this study is a qualitative method with a descriptive approach because this study aims to obtain a complete picture of freediving as a form of alternative tourism in Tulamben, Bali. The time used is cross-sectional. The technique of collecting data using a questionnaire consisting of two parts, the first part aimed to get data about the profile of freediver as a tourist and the second part related to their response to about freediving as a form of alternative tourism in Tulamben. The unit of analysis of this study is

Tourism Research Journal, Volume 4 (2), 2020 
The Significance of Destination Image For Freediving as a Form of Alternative Tourism in Tulamben, Bali

about 100 tourists visiting a diving site in Tulamben. The sampling technique used is non-probability sampling with a purposive sampling approach.

The scope of This research is to identify the level of satisfaction of freedivers who come to Tulamben for underwater tourism activities and the development of strategies that produce solutions. Furthermore, of course it is treated as sustainability to develop multifunctional tourism focused on goals. Therefore, a competitive advantage should be created in focus rather than providing cheap products applying more to the brand name creation of tourism areas. Such a requirement applies to increasingly become a more important area for diving tours in Tulamben.

Of course, surface formation from the profiles of divers who come to Tulamben for underwater sports tours is the only record of the study's purpose. Reliable measuring tools to investigate the points mentioned above are through their opinions and thoughts on the underwater world, tourism products and services, as well as a holistic approach to the profile of free divers coming to Tulamben with the purpose of diving has been used in research (Watts et al., 2001). The scope of the study is freediver divers who visited the Tulamben region between June and September for diving. These months have basically been chosen because they are high season for Tulamben related to these underwater activities.

\section{Result and Discussion}

\section{Demographic Profiles and the Characteristics}

The result of the data processed for the demographic profiles and the characteristics of the respondents or freediver visiting Tulamben showed as follows:

Based on preferable sites, it can be seen that the respondents most visited USAT Liberty Shipwreck which was as much as $41 \%$. While the other $19 \%$ Coral Garden, 16\% Drop Off, 14\% Kubu, the remaining 10\% visited other sites. The number of tourists visited USAT Liberty Shipwreck because of the popularity as well as being one of the centers of the Tulamben dive sites, also due to the condition of the shore and the sea which are still quite well maintained and the natural scenery and surroundings are very beautiful. That is why many tourists are interested in visiting these sites because they can get an unforgettable and memorable travel experience. In addition, the communities around Tulamben and Karangasem area are also very friendly and kind, so they can provide a sense of security and comfort for tourists who visit. Another advantage is that Tulamben lies in a strategic location in the middle of the cluster.

Based on gender, the visitors coming to Tulamben are dominated by female visitors, then by male visitors. The secondary data shown that this is caused by Tulamben offers exotic views and has not been visited by many tourists. What's interesting about Tulamben is the charming sunset and the

Tourism Research Journal, Volume 4 (2), 2020 
The Significance of Destination Image For Freediving as a Form of Alternative Tourism in Tulamben, Bali

beautiful stars in the sky. Moreover, for visitors who also like doing lighter activities such as snorkeling and underwater modeling, Tulamben's underwater beauty is amazingly charming.

Based on age, it can be seen that Tulamben has most visitors at the age of $20-30$ years $(32 \%)$. At this age, most people have the most affordable power in the term of time and money. While the other age range also shown these results (27\%) 31-40 years, (21\%) 41-50 years, (8\%) older than 50 years, the remaining $8 \%$ younger than 20 years. Most age groups admit that Tulamben has multiple attractions like a historical shipwreck that provides values that can still be enjoyed and interesting natural landscape for taking photos from any position. Whereas there are several dive spots that will make travelers enjoy the natural sea. The naturalness of nature provides a comfortable home for some underwater natural animals. The large, healthy-looking reefs are a safe place for some small fish that swim in and out of the reefs.

The type of traveler shows more dominant (56\%) respondents traveling with their friends, then followed by traveling with a family of $28 \%$, through the $11 \%$ Tour Group and traveling alone at 5\%. This shows that the freediver visiting Tulamben is more pleased to be in tandem with their colleagues. In general, the respondents are employees who work in big cities who are visiting to eliminate the workload, since every day these groups of people always congested on the road to work from their homes.

Based on respondents' origin continent, it shows that the most dominant respondents originate from Europe around 37\%, then from Asia (28\%), and follow by America (21\%), and the rest 14\% come from other continents. These numbers prove that Tulamben is well known even for worldwide freedivers as great places for training and any related underwater activities.

\section{Tulamben Destination Image}

The result of the data processed about Tulamben Destination Image for respondents or freediver visiting Tulamben showed as follows:

For statement "Tulamben offers good condition of coral reef ecosystems the average rating of respondents/freedivers is 3.9. Based on the interpretation table, the value of 3.9 falls into the Good category. It means that condition of coral reef ecosystems offered to freediver visiting Tulamben is good.

For statement "Tulamben has a wide diversity of marine flora and fauna", the average rating of respondents/freedivers is 3.48. Based on the interpretation table, the value of 3.48 falls into the Good category. It means that the diversity of marine flora and fauna of the Tulamben is good.

The statement "Tulamben has a good name and reputation" shows that the average rating of respondents/freedivers is 3.48. Based on the interpretation table the value of 3.83 is in a Good category. According to tourists visiting the Tulamben, this means that the Tulamben has a good name and reputation. 
The Significance of Destination Image For Freediving as a Form of Alternative Tourism in Tulamben, Bali

For statement "Tulamben has suitable depth and level for freedive training ", the average rating of respondents / freedivers is 4.32. Based on the table of interpretation the value of 4.32 falls into the Very Good category. This means that tourists visiting the Tulamben believe that the depth variations are mostly good in Tulamben.

For statement "Tulamben has supportive current speed ", the average rating of respondents / freedivers is 3.32. Based on the interpretation table, the value of 3.32 is included in the Fairly Good category. It means that according to freediver visiting the Tulamben feel the current speed of the Tulamben are quite good for freediving activities.

For statement "Tulamben has good underwater visibility", the average respondent / freedivers scores 4.21. Based on the interpretation table the value of 4.21 falls into the Very Good category. This means that freediver visiting the Tulamben agrees that Tulamben underwater sites most of the time has a very good visibility.

For the statement "Tulamben provide adequate access to the dive sites", the average respondent/freedivers votes at 3.71. Based on the interpretation table the value of 3.71 is in the Good category. This means that tourists visiting the Tulamben agree that the Tulamben offer good access and infrastructure to reach the dive sites if freedivers want to have their training or fun dive sessions.

According to respondents/freedivers visiting the Tulamben, the overall destination image of Tulamben is 3.8. The 3.8 value is in the Good category. This is shown that Tulamben has a good overall destination image for freedivers.

\section{Freediving as a Form of Alternative Tourism}

Although tourism is not the only purpose of freediving, since it covers many benefits (fun freediving, sporting events, etc.), still can be concluded that tourism and freediving are interrelated phenomena and the relationship between them changed significantly. Freediving in contemporary tourism has a perceptive role, but it is also an important content to state that visitors become active participants in various freediving activities (Ruppe and Barstad, 2001). It becomes not just content to stay, but often the main motive for traveling to a particular tourist destination. This relationship between freediving and tourism leads to the development of a specific type of tourism. Freediving in tourism appears to be perceptive, but it is also important to show that visitors become active participants in various freediving activities. In this context, it can be concluded that tourism and freediving destinations have a lot in common.

Freediving as alternative tourism has an educational function expressed through learning and mastering certain sports skills. However, it is not only increasing the educational level of visitors, but this feature has some educational influence that manifests itself by creating habits for practicing certain sports and recreational activities. Another benefit in freediving as an alternative tourism can also be seen in alternative tourism's social function because people are

Tourism Research Journal, Volume 4 (2), 2020 
The Significance of Destination Image For Freediving as a Form of Alternative Tourism in Tulamben, Bali

introduced, bringing together regardless of social and other differences between them. Freediving as one way of sport tourism is almost always tied to travel to different places and along with tourism, it becomes way to connecting people among nations. In addition, the top sports achievements are the best tool for the promotion of individual countries.

The economic function of recreational consumption of sports is achieved through various sports products of the tourist market, thus producing additional economic effects. It is also known that economic functions have extreme importance for the economic development of receptive tourism countries such as Tulamben. Regarding this advantage, games and communicability are basic elements of sports activities for the holidays, so it should be placed and accent sport tourism. Of course that should not be ignored even recreational - the health aspect that occurs as an element (Green, 2004).

\section{E. Conclusion}

The obvious development and rapid growth in the freediving field bring contributions in many aspects for alternative tourism in Tulamben. This activity provides a symbiosis with tourism that needs new challenges and will reach the top of the exciting business sector. Although this shape of alternative tourism in Bali and Indonesia developed and very popular in our country, it is still in the stage of occurrence and formation. However, we can see some freediving sport events that have "power" to mobilize many visitors. With that kind of view it is safe to say that the potential of freedive as alternative and sports tourism sufficiently used.

Freediving and alternative tourism activities seem to be thriving together and in line to this day. Such sports tourism components are undoubtedly an industry that has an important influence shown by profits that constantly increasing and feedback, without experiencing almost no shocks and repercussions of the global economic crisis. As a supporting facility, modern kind tourism start to involves providing healthy diet and suitable accommodation but does not ignore the content of active recreation, recreation, cultural relaxation, sports, with music and entertainment. In addition, current tourism trends connect sports and health, and many other benefits especially active vacations with kinesiological recreation of sports content, relaxation of mind and body entertainment and others.

Based on the above analysis, it can be described that Tulamben has a good destination image for freediver. This can be seen from the rate of repeat visits made by tourists by $58 \%$ of 100 respondents. Then it was concluded that freediving could be potential alternative tourism in Tulamben. Besides that, respondents also considered that the Tulamben was a very good place to do many freediving related activities such as training, workshop, competitions, and other events. This study's results are expected to encourage the government and business people to make better promotions since Tulamben have been

Tourism Research Journal, Volume 4 (2), 2020 
The Significance of Destination Image For Freediving as a Form of Alternative Tourism in Tulamben, Bali

considered good by freedivers who have visited Tulamben and could attract more visitors in the future only by words of mouth.

In order to further support the results of this research, further research is needed which is more in-depth about the motivation of freedivers visiting the Tulamben. The Government and business people can design attractive programs for visitors to increase the number of visitors to the Tulamben.

\section{REFERENCES}

Broadwater, John D. (2001). Digging Deeper: Deepwater Archaeology and the Monitor National Maritime Sanctuary. Virginia: National Oceanic and Atmospheric Administration, Newport News.

Cederlund, Carl Olof . (2001). Archaeology in Marine Environment in Sweden. New York: Kluwer Academic Plenum Publishers.

Cooper, Fketcher, J., Gilbert, D., \& Wanhill, S. (1995). Tourism, Principles and Prantice. London: Logman.

Delfs, Robert. (2003). USAT Liberty Shipwreck Tulamben. Cambridge: Academic Press.

Edney, Joanne. (2006). Impacts of Recreational SCUBA Diving on Shipwreck in Australia and the Pasific. Journal of the Humanities and Social Sciences, Vol. 5, No. 1 / 2, November (combine issue), page 201-233.

Fasandra, F., Mumin, A. T., \& Nurbaeti, N. (2019). Analysis of Potential Mountaineering Tourism in Mount Gede Pangrango National Park in West Java. TRJ (Tourism Research Journal), 3(1), 47-55.

Ghautama, Gatot. (2011). Underwater Archaeology in Indonesia. International Seminar on Underwater Archaeology. Singapore: Museum of Asian Civilization.

Green, Jeremy (2004). Maritime Archaeology. London: Elsevier Academic Press.

Ivanova, Desislava., Nihrizov, Hristo., \& Zhekov, Orlin. (1999). The Very Beginning. Human Contact With the Underwater World. Think Quest. Archived from the original on 2009 12-18. Retrieved 2009-09-06.

Junaedi, Didien. (2007). Konsep Pengembangan Wisata Bahari di Indonesia. Jakarta: Direktorat Geografi Sejarah, Ditjen Sejarah dan Purbakala, Kementrian Budpar.

Nofiyanti, F., Mayasari, I., \& Parwoto, B. D. (2020). Tourism Attractions and Visitors Perceptions on "Negeri di Atas Awan", A New Tourist Destination in Citorek Kidul Lebak Banten. TRJ (Tourism Research Journal), 4(1), 93-103.

Rebikoff, Dimitri. (1995). Free Diving. London: Sidgwick and Jackson Publisher.

Ruppe, Carol., \& Barstad, Janet F. (2001). Underwater Archaeology. New York: Kluwer Academic Plenum Publishers.

Soeparno. (2010). Membangun Negara Maritim dalam Perpektif Ekonomi,

Tourism Research Journal, Volume 4 (2), 2020 
The Significance of Destination Image For Freediving as a Form of Alternative Tourism in Tulamben, Bali

Sosial Budaya, Politik dan Pertahanan. Seminar Nasional Indonesia Maritime Institute (IMI), Jakarta.

Sopher, David E. (1965). The Sea Nomad: A Study of Maritime Boat People of Southeast Asia. Singapore : National Museum.

Watts Jr., Gordon P \& Ian, Roderick Mather. (2001). Public Programs; An Overview Underwater Archaeology. Cambridge: Academic Press.

Wells, Tony. (1995). Shipwrecks and Sunken Treasure in Southeast Asia (With over 450 Wrecks including the Flor Do Mar). Singapore: Times Editions Pte Ltd.

Tourism Research Journal, Volume 4 (2), 2020 